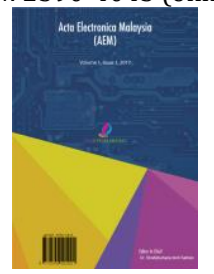

\title{
PDK FIRE FIGHTING MANAGEMENT SYSTEM
}

\author{
Shahreen Kasim ${ }^{1 *}$, Eniasharmila Karunakaran ${ }^{1}$, Nurul Aswa Omar ${ }^{1}$, Norfaradilla Wahid ${ }^{1}$, Hanayanti Hafit ${ }^{1}$, Ayu Alyani ${ }^{2}$ \\ ${ }^{1}$ Soft Computing and Data Mining Centre, Faculty of Computer Science and Information Technology, Universiti Tun Hussein Onn, Johor, Malaysia \\ ${ }^{2}$ Findbulous Technology Sdn Bhd, Batu Pahat, Johor \\ *Corresponding author email: shahreen@uthm.edu.my
}

This is an open access article distributed under the Creative Commons Attribution License, which permits unrestricted use, distribution, and reproduction in any medium, provided the original work is properly cited.

\begin{tabular}{|c|c|}
\hline ARTICLE DETAILS & ABSTRACT \\
\hline Article History: & Nowadays, system seem to be pioneer in the development of growth IT (Information Technology). PDK Fire Fighting \\
\hline $\begin{array}{l}\text { Received } 3 \text { July } 2017 \\
\text { Accepted } 3 \text { October } 2017 \\
\text { Available online } 10 \text { November } 2017\end{array}$ & $\begin{array}{l}\text { Management System is a system going to be develop for the company of PDK Pyrosev Fire Electrical Engineering } \\
\text { company. PDK company types of record mostly recorded manually. Paper and files are used to record customer's } \\
\text { profile, payment, quotation, invoice, delivery order, purchase order and checklist consists of Hose Reel, Fire Alarm, } \\
\text { Hydrant, Automatic Sprinkler and Carbon dioxide (CO2). Besides that, this system is to keep track on invoice monthly }\end{array}$ \\
\hline Keywords: & $\begin{array}{l}\text { payment for each and every company. Furthermore, through this system it alerts on the expired date of fire } \\
\text { extinguisher by popping out a remainder. In addition, with the help of this system, the management of this PDK }\end{array}$ \\
\hline $\begin{array}{l}\text { Carbon dioxide (CO2), Hose Reel, } \\
\text { Fire Alarm, Hydrant, Automatic } \\
\text { Sprinkler. }\end{array}$ & $\begin{array}{l}\text { Company has become more systematic in the aspects of managing procurement of goods and services, sales, inventory } \\
\text { and maintenance. Due to this the probability data getting lost and being repeated will be lesser. The interface used for } \\
\text { this system is based on current needs and system requirement. Besides, this system is received from different aspects }\end{array}$ \\
\hline & $\begin{array}{l}\text { to assure the effectiveness. PDK Fire Fighting is develop using PHP } 5 \text { programming language, mySQL database and } \\
\text { the methodology used is Object Oriented Software Development. As a conclusion, management system eases the } \\
\text { company in terms of Procurement, sales. Inventory and Maintenance. }\end{array}$ \\
\hline
\end{tabular}

\section{BACKGROUND STUDY}

Today, fire and rescue remain a mix of full-time paid, paid-on-call, and volunteer responders. Many but not all urban areas are served by large, paid, firefighting teams. Firefighting is one type of job towards leading the fight against fire [1]. Firefighting handles total fire protection system which basically consists of HFC 227ES system, carbon dioxide system, foam system, fire water spray, Inertec system (Inert gas) and fire detection system. Besides that, fire extinguisher also is apart from firefighting. Main extinguisher consists of carbon dioxide $2.27 \mathrm{~kg}$ and dry powder $9 \mathrm{~kg}$ with Bomba specification is a part of SIRIM approval with national standardization and accreditation body.

PDK Pyrosev Fire Electrical Engineering is a well-known and establish company in Sungai Petani, Kedah. This company handles goods in firefighting equipment such as hose reel accessories, fire hose reel, European fire hose reel, hose reel nozzles, hydrant equipment such as fire hydrant valve, wet and dry riser equipment nozzles, flow control equipment, hose reel cabinet, foam hose reel, smoke detector, sprinkler and fire extinguisher of dry powder and carbon dioxide [2]. This company has taken place doing electrical wiring, installation and maintenance firefighting business in Perlis, Perak, Pahang, Kelantan, Terengganu and Johor. Most of the project involve are major project which took place in all schools around Kedah area, Pejabat Pendidikan Daerah (PPD), hotels, Mediterranean Shipping Company (MSC) clothing warehouse, Kamdar Sungai Petani, Kamdar Alor Setar, Kamdar Langkawi, factories and many other company more.

PDK company is well specialized in maintenance fire protection system, electrical wiring 3 phase, sprinkler system, hose reel system, carbon dioxide gas system, $3 \mathrm{M}$ novex, clean agent Int 55/100, specialized in water storage tank, pump system, installation of fire alarm panel and gen set 1000KVA [3]. This company consists of one owner, seven employees and one clerk who perform the entire filing job. Basically, this company has no any proper system. It consists of four computers where two computers for the admin to work on with the paperwork and documentation related to invoice, quotation, delivery order, purchase order, and checklist consists of hose reel, fire alarm, automatic sprinkler, hydrant and carbon dioxide. Those checklists are for maintenance inspection where PDK Company will inspect other company under PDK service monthly.
Company sub-main businesses are fire extinguisher business. There are certain steps if a customer wants to set up a fire extinguisher in his/her shop or company. Every time the date of the fire extinguisher get expires the owner needs to remind himself or the clerks have to remind him that the date of fire extinguisher already expired [4]. Therefore, they need to renew a new one which is RM15 for the services and if the extinguisher is condemn, advisable to change a new one. There are about 20 regular customers. One dry powder fire extinguisher cost about RM90 and the carbon dioxide fire extinguisher cost about RM120.Everytime customer come to buy a dry powder cylinder or a carbon dioxide cylinder clerk always provides receipt manually to the customer as prove for the payment. The main supplier for this PDK company is Unique Fire Industry Sdn Bhd(UFI) located in Puchong Selangor.

PDK Pyrosev Fire Electrical Engineering Company system, so far all manually done documentation such as invoice, quotation, purchase order, reminder of fire extinguisher maintenance, latest stock result and report of invoice sales. Therefore, owner and clerk always need to work more on paperwork and checking specification with all those documentation that they have made [5]. Sometimes end of the year when they need to calculate how much the amount the company have earn where the clerks need to sit for almost one whole day in office to count on the invoice amount for that particular month. During that moment there will be some inaccuracy and again they need to calculate all over again from the beginning. This pressures the clerks and also the owner.

Next is that when a customer one's to buy a fire extinguisher the clerk might misplace the identity and details of the customer as there is much paperwork to be done, this causes the misunderstanding between customer and owner. Another important thing is that owner always forgets when the fire extinguisher is being expiring, so clerk always need to verify the calendar and reminds the date of expire to owner. In addition, owner has many projects deals with maintenance every month, therefore owner reminds himself by writing them in a diary book.

\section{REVIEWING THE EXISTING SYSTEM}

The systems that have almost similar properties and serve the same purposes are reviewed. There are three systems that being reviewed with 
PDK company system [6]. The reviewed systems are Steel Recon Industries online system, Kidde Fire Fighting online, and Fenwal Protection System which basically major on fire extinguisher and firefighting accessories business. Kidde Fire Fighting Company, Steel Recon Industries and Fenwal Protection System Company also deal with proper management system.

\subsection{Steel Recon Industries online system}

Steel Recon Industries or known as SRI which committed to provide the most comprehensive and reliable firefighting equipment and services to protect properties. SRI with modern facility allows the company to manufacture high quality hose reel, hoses, fire extinguisher, and cabinets by using advanced computer aided manufacturing method, a CAD/CAM operated sheet metal machine, automated paint shop for surface pretreatment and powder painting.

This system basically has only 2 modules where, inventory system and information system. Inventory system is that SRI is the main manufacturing company, so they have their own inventory system of raw material that they bought and the sell out the product which they had manufactured. Due to this stock in and stock out of inventory it eases the SRI system to know their inventory. Besides that, owner can verify how many stock in and out per day.

On the other hand, the information system is much broader. This shows SRI system provides more information in terms of business specification since it is a manufacturer company. Information such as that company profile, products about firefighting, shops online, news and career. That informative information from SRI Company is very important for online users especially.

Overall this system benefits online user more and also owner in terms of inventory view. SRI company system was develop using HTML language and supported by mySQL.

\subsection{Kidde Fire Fighting}

Kidde Fire Fighting (KFF) online system is a UTC fire and security company. This system is similar as SRI Company. Instead Kidde Fire Fighting (KFF) system include log in page for administrator. This company more towards raising the profile industry provide training to members about firefighting and supply product that consists of foam firefighting, firefighting equipment, nozzle specialized with big flow pumping solution, portable and fire apparatus foam system and hose products.

System contains of providing information too where unit by unit and help out new member with training courses. Overall this system benefits online user more and also owner in terms of inventory and business view.

\subsection{Fenwal Protection Systems}

Fenwal Protection System (FPS) online system is the leading provider of fire protection for mission critical facilities. This system is similar as KFF. Besides, Kidde Fire Fighting (KFF) system include log in page for administrator. This company more towards raising the profile industry provide training to members about firefighting and supply product that consists of clean agent suppression system, smoke and alarm device nozzle specialized with big flow pumping solution, portable and fire apparatus foam system and hose products.

System contains of providing information about employment opportunities and all contacts details of the company.

Overall this system benefits online user more and also owner in terms of inventory and business view. Fenwal Protection System company system was developed using HTML language.

In the reviewed management system, seems that Steel Recon Industries system, Kidde Fire Fighting system and Fenwal Protection System are not fully complete rather than PDK Pyrosev Firefighting Management System. Firstly, the login username and password, SRI company doesn't have any while KFF company, Fenwall Protection System and PDK company has it. These shows KFF, FPS and PDK Company have high security in terms of login. Next based on inventory system and maintenance system of SRI company and KFF company, SRI company both have inventory and maintenance system neither KFF system don't have either one as goes to FPS. PDK Company has inventory and maintenance module based on firefighting SRI, FPS and KFF companies both don't have alarming alert of expiring fire extinguisher but PDK Company that going to be develop consist of this alarming alert system. This is extra advantages of PDK system rather than two other systems. All three systems have properly ordered documentation. Next, programming language use for SRI Company is HTML language; KFF Company uses HTML and PDK Company uses PHP 5 SRI Company does not contain sales module and procurement module since it's a system for user use more. Procurement module for KFF Company doesn't exist as same goes to FPS Company while PDK Company consists of sales module and procurement module

Lastly is that PDK company has extra function of alarming alert system of fire extinguisher due date expiring This ease clerk and owner to remind themselves that the particular company need a renewal of a new fire extinguishers or service fire extinguishers.

\section{IMPLEMENTATION OF SYSTEM}

Many system interfaces will be implemented and also the related coding. The main interfaces of web based application basically come with 4 module which are procurement module, sales module, maintenance module, and inventory module to run different task separately. The implementation and coding of the PDK Fire Fighting Management system will be described by each function interfaces.

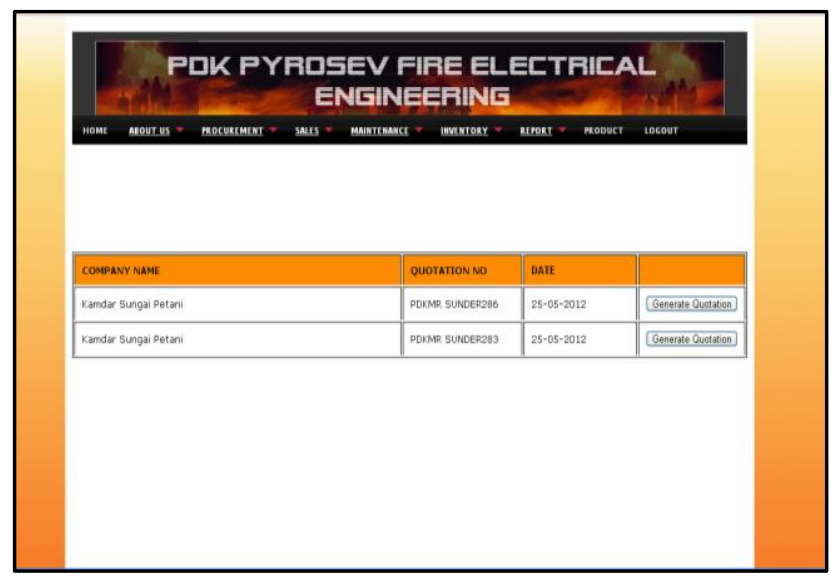

Figure 1: Code of view quotation

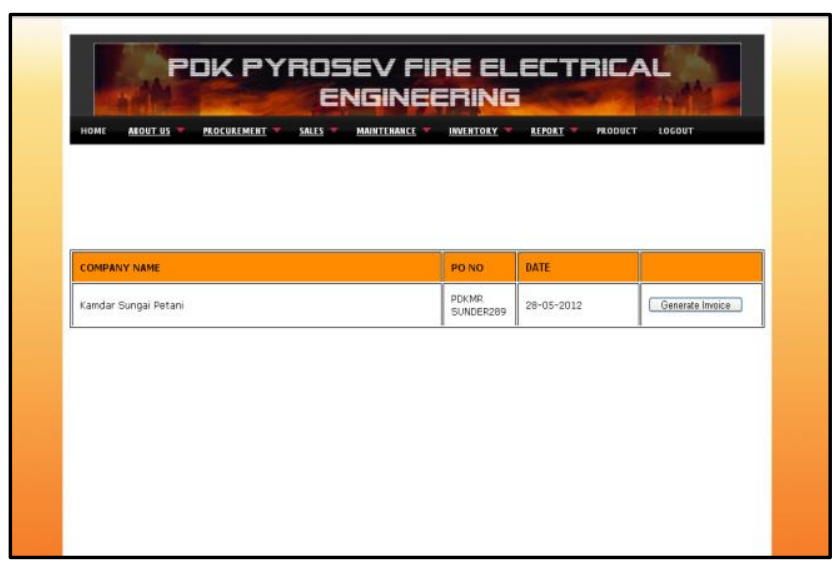

Figure 2: Code of view new purchase order

View invoice function is where latest invoice can be view accordingly.

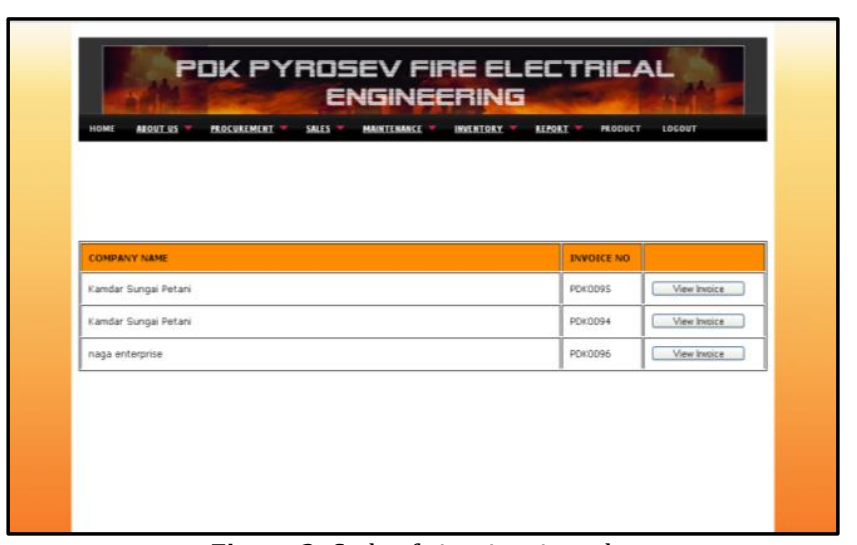

Figure 3: Code of view invoice sales 


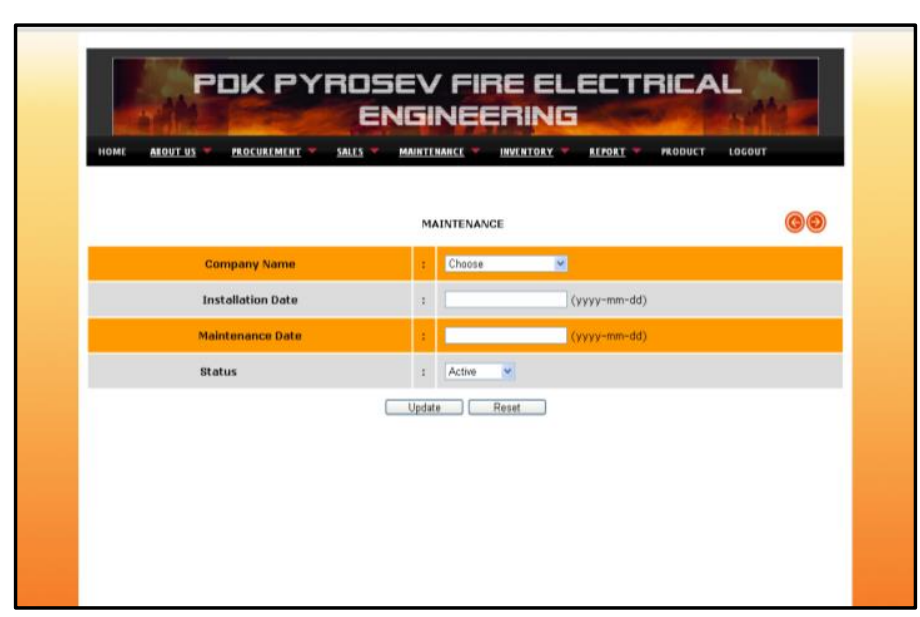

Figure 4: Code of update installation date

\section{USER ACCEPTANCE TEST}

In this testing phase, the stakeholder was met and the system was put to test. The users of the system are the staffs of the PDK Pyrosev Fire Electrical Engineering and the PDK owner, Mr Karuna and few clients. User testing forms was given to the staffs in the company as well as the owner to evaluate the system

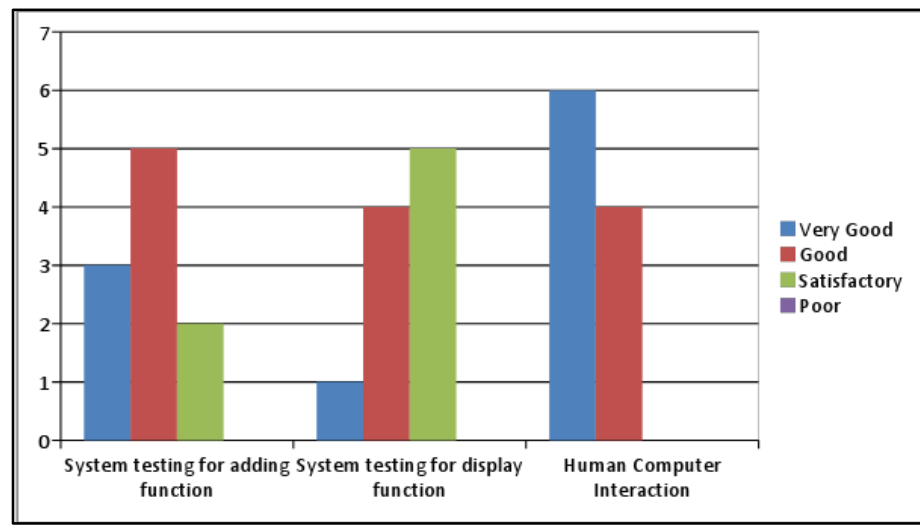

Figure 5: Bar Graph produced based on the user acceptance testing

\section{CONCLUSION}

The overall objective fulfillment of the PDK Fire Fighting Management System is satisfactory. The system being develop is web based application. According to the two-testing taken place in the previous phase of the software lifecycle, the testing showed a good response by the user as well as the test cases generated in the system testing. The objective of the system is to develop a management system on firefighting and fire extinguisher reminder maintenance system where the system flow will be manageable in orderly and accordingly. Clerk can update, add and delete product order by client; also update installation and maintenance date of fire extinguisher. While procurement and sales clerk update information of quotation and invoice and owner can view those particular information and updates clerk work on it

For the future work, it is recommended to improve on more modules to ease client especially in providing sufficient information. This system can be upgraded by providing better module for product maintenance and also fire extinguisher maintenance. Besides that, module inventory can be implemented.

After the development of the system, the advantages of PDK Fire Fighting Management System are identified as follows:

a. The staffs update the remainder date of particular date of fire extinguisher

b. The owner can view monthly report of invoice easily and also quotation report.

\section{REFERENCES}

[1] Fire Department. 1997. Firefighting Procedures. Ladder Company Operations Private Dwellings, 3 (4), 1-35. Retrieved on 1987, from DOI: $10.1007 / \mathrm{BF} 01040585$

[2] American Bureau of Shipping. 2005. Fire Fighting System. Retrieved on May 2005, www.eagle.org

[3] Department of Interior Bureau. 2000. Firefighting and Fire Prevention. Care and Inspection of Firefighting Equipment, 5 (2),12-15.

[4] SRI. 2011. Leading the Fight Against Fire. Selangor(Malaysia): Firefighting Catalogue. Physiological Aspects of Fire Fighting, in Charles o.Dotson. Mallorca. pp 280-282.

[5] Taylan, 0. 2010. The Strategic Role of An Organization in Developing A Modern Information System. Journal of Naval Science and Engineering, $6(3), 25-39$.

[6] George F.G., Batra, D., Valancich, J.S., Hoffer, J.A. 2007. Object Oriented System Analysis and Design. $2^{\text {nd }}$ ed Pearson Parentice Hall 